\title{
Spaces of becoming - Space shapes public and public (re)shapes their own spaces
}

\author{
Vaishali AGGARWAL, Bauhaus-Universität Weimar; Germany
}

\begin{abstract}
Fights over the 'right to the city' have emphasized the interests of the four main actors within the city development of India since the first cases of revolting social movements in Delhi. The four actors can be classified as the social movements, the public, media and the government. The case of India Gate in Delhi is illustrative not only of how the differences between the actors come into surface, but of also of how these actors change their priorities, their stance and their tools, in order to secure their position in the city. Many scholars have analysed the role of social movements and how it evolves in the process. But what about the role of government as an entity that is in between the interests of social movements, public and media? How and why do they change their stance when a movement takes place? What are their limitations? The India Gate case can give the answers to these questions, as it examines the multiple transformations of this space over time. This paper emphasizes on the idea of Space. How space shapes public and public (re)shape their own spaces. India gate. This space has been stuck between the idea of being a space or a branded space. It was assumed that media plays a prominent role in acting like a watchdog in democracies, but this paper looks at how media if used rightfully can be forced for a good in oppressive regimes and therefore, a vigilant and alert media can act as an external trigger or an emergency- wake up call for the youth of India to take the cause of freedom seriously. Rightfully as put up by Ritish (2012), an external event or issue may allow for the manifestation of a flash fandom in the form of flash activism. Since, social movement's needs mass media attention for amplification of their claims, the media also join the movements too create the news. Lastly, the consequences of the media coverage for social movements, in terms of organisation, reaching political change and obtaining favourable public opinion is comprehended in three different case studies.
\end{abstract}

\section{Keywords}

Right to the city, Social movements, transformation, democracy, flash activism, flash fandom, Youth of India.

\section{Introduction}

\subsection{Importance}

The research aims to broaden the understanding of the importance plazas have in urban conflicts between government, public, media and social movements and conclude how these plazas acts as the spaces of becoming by analysing the case study of one such relevant conflict from the city of Delhi. Looking at the role of plazas as a public space and how movie 
from an Indian cinema can take people outrage to the street and influencing series of social movements bounded to the notion of 'right to the city'. It also provides an overview on why social movements need the mass media (and vice versa) and how media activism helps in getting justice. After that, the literature state of the art is introduced in connection with the broader topics mentioned in the theoretical framework. Emphasis is put to the description of actual conflicts between social movements, public and government. The aim of the research was developed on the case of Nirbhaya Rape case in Delhi, based on the former social movement no one killed Jessica and movie Rang de Basanti (Paint it saffron) in 2006. As in the case of Nirbhaya's rape case which turned out to be international sensation as it played a very important and ambivalent role in resolving the gap between the public and the government. However, this particular social movement did not resolve the situation but rather than acting as an isolating phenomenon, it brought a social change. The research questions are formulated to get an insightful view of the processes from the viewpoint of the government. It also provides an overview of the way in which social media and digital networks contextualized and scrutinised the relation between social movement and activism.

\section{Theoretical Framework}

\subsection{Delhi - a contested space}

The images of the cities plays an important role in the formation of the urban identity where the conflicts in the city raises the questions about the nature of the 'political' and of local democracies. Urban identities creates a platform, which associates between specific places, the production of places, and visualises the basis of its construction to an extremely unambiguous place, media image and temporary space. According to Enrico (2013), conflicts marks the crisis of the 'political', its void or absence, while it also delineates potentials for its revival. Delhi, a city in palimpsest is a combination of layers of things \& identified with the cultural manifestations along with spatial identities. However, in Delhi, these combinations and the cultural identities is more complicated because of the dimension with its colonial past. As a (post) colonial city, Delhi has fragments of colonial spaces.

\subsection{India gate - Background}

India Gate is such space with a concept that links the mental and the cultural, the social and the historical perspective. Thus, the 'culture of contestation' adds a new dimension along with the 'culture of informality'. City like Delhi hinges the relation between the space and the society. It is an inseparable tangled knot between spatiality and sociality. As Lefebvre (1991: 26) long ago also pointed out the curious condition that space is both a means of production and a product of it. It stands high in the politically dominant area in the administrative seat of India. Every year Republic day parade takes place at this place, which is witnessed by thousands of people, symbolises power and further acknowledges the feeling of patriotism. However, as it evokes in the architectural style and is surrounded by numerous parks, everyone favours this place. Domination over the space $>$ creation of a 'counter-space'.

\subsection{India gate as a place for Protestants}

The conflicts shapes in a specific spatial and material setting. This is made possible by the placement of things, the system that establishes visibility, accessibility of areas for the 
production of human action in the city. Since the discourse about the place is ignored, therefore Lefebvre's "spatial Practice" inhabits my attention (Lefebvre 1991: 33-46) where he certainly does not mean that the representational or discursive is unimportant. He focuses on the reproduction of the spatial and social urban order where subtle behaviour adjustments are more explicit and visible. India gate is a war memorial, which is both inhabited and constructed as a memorial landscape complex. It was erected not only for an attempt to 'fit in' with the existing and traditional spaces of commemoration, but altered and created new spaces that determines commemorative strategies, entertain masses. This sensuous and spectacular nature of war remembrance draws attention to the centrality of sight, sound and touch for the remembrance of activities. Since, the location and the importance of this place makes it suitable for a place to protest, the question of losing the impact also lies there as the space is under heavy security. Thus the 'becoming' of this space also adds to its labyrinthine quality which may cause in losing the controlling gaze of the spatial order and enters a world of escape, mystery, danger and desire.

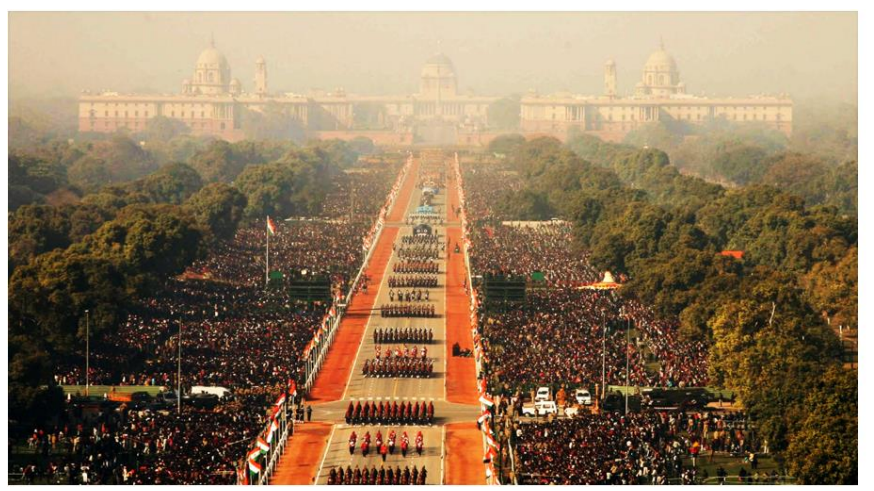

In line with president's house \& Rajpath Centrality \& political importance

Power shows ist dominance Symbolic place - centre of the city \& governmental buildings

Every protest is centralized

Initially used to be a picnic place

Power balance is shown

A place where power plays important role, now acts as a field of conflicts/riots

Figure 1- Protests, conflicts \& power dominance at Republic day Parade

\section{Social movements in urban sphere}

\subsection{Why social movements?}

Movements are necessary for creating an identity construction about what things were but reflecting aspirations with an idealized past bridging with future. This conceptualisation of a space endows 'new spaces' without any effort to 'place' vulnerabilities as a consequence for social relations. Movements produce the idea of 'degenerate Utopias', 'dialectical utopianism' of the 'process' and 'form' which helps in flourishing active society. Society is a social creation where Social change is beyond the control of the individual.

\subsection{Why social movements?}

"Social movements can be viewed as collective enterprises seeking to establish a new order of life. They have their inception in a condition of unrest, and derive their motive power on one hand from dissatisfaction with the current form of life, and on the other hand, from wishes and hopes for a new system of living. The career of a social movement depicts the emergence of a new order of life" (Blumer, 1969, p. 99). 
A social movement is a form of "purposive collective actions whose outcome, in victory as in defeat, transforms the values and institutions of society" (Castells, 2004, p. 3).

A social movement is "the effort of a collective actor to take over the 'values', cultural orientations of a society by opposing the action of an adversary to whom he is linked by relationships of power" (Touraine, 1995, p. 239).

Based on these different definitions the most important aspects of social movements are negation of dominant values, institutions, adversary, dissatisfaction, mobilising demolishing structures, etc. Herbert Blumer therefore identified four stages of 'social movement's' lifecycles, which are as follows:

1. Emergence

2. Coalescence

3. Bureaucratization

4. Decline

Since success and failure are two sides of the same coin, the question of why movements fail simply mirrors the question of why movements succeed. On one hand, social movements succeed by gaining attention and raising public awareness, but this does not necessarily influence policy-making. Though over the time, movements may achieve successes and face hindrances which might face counter movements or generate new movement altogether which leads to variety of outcomes, including Institutionalisation, indulgence, suppression, or abeyance until the future period of mobilisation. The cry and demand for 'right to the city' has grown into a global catchphrase that is tossed around by activists and policymakers. While Harvey (2008) claims that 'right to the city' changes oneself by changing the city, the UN on the contrary believes that 'right to the city' demands for instinctive flexible meaning for dignified and secure existence in cities. The 'right to the city' is the right of all the inhabitants to permanently and temporary use, occupy and produce inclusive and sustainable cities for present and future. It's an existing co-operative and diffuse human right that developed from bottom-up approaches and belongs to all the inhabitants of cities on the basis of their common interest. The 'right to the city' belongs to the present and future generations which means involving the access to urban resources, services, goods, and opportunities of city life for all the inhabitants who can participate in the making of city.

As indicated by Lefebvre (1996), urban space offers its inhabitants 'the right to the city'. This right includes openness, flexibility, the recognition of differences, the right to be included, the right to develop an individual or collective identity, and autonomous decision making, alongside an unrestricted access to resources.

\subsection{The role of the local governments}

In the conflict between social movements and government, four groups could be identified as the main actors: the social movements, public, media and the government where very actor has its own motives and characteristics. The combination of the traditional role of municipalities to keep their citizens content and, in parallel, to implement viable transformations in the urban space is seeking new challenges. Nevertheless, as Hackworth 
(2007, p.15) argues, the relatively regulatory state of the mid-twentieth century has been supplanted by a neoliberal version that seems itself to be regulated by local capital.

Even if we look at the role of a local government as 'neutral' in this new era that the 'welfare character' is replaced by the 'regulatory character', there are restrictions that have emerged during the last decades, indicating that a 'neutral' standpoint in dealing with the urban conflicts cannot be achieved easily. However, local authorities don't have neither the economic nor the political power that a state has. Thus, they become more vulnerable to the projections of bond-rating groups,

"The idea that municipal governments should behave as economically efficient, businessfriendly, anti-deficit entities is now an axiom rather than a debated policy shift among city managers". So, after all this 'autonomy' comes along with "powerful limitations on the choices that city officials can and cannot make" (Hackworth, 2007, p.20).

\subsection{Power of media leading to a social movement}

The social movement and mass media are mutually dependent; it draws the attention and creates newsworthy events. Since the intensive exposure of internal struggles and irregularities within the movement eventually resulted in the gathering public support, the former social movement already created a sensation among the people for justice. However, due to the non-institutionalisation position of social movements, the relationship between movements and the media is characteristically more asymmetrical than the interaction between politicians and the media, which results in a failure of social movements sometimes. For example as happened in the movie influenced social movement.

\section{Social movements in the case of Delhi}

\subsection{How does film affect the audience's perceptions about government and} freedom?

As rightly said by Ritesh (2012) Rang De Basanti (Paint It Saffron) was a patriotism- and social change-themed Bollywood film that was strategically released in India and other countries on January 26, 2006, India's Republic Day (which commemorates the day when the Indian Constitution came into effect). Despite the international accolades, Rang De Basanti's greatest legacy is its role (unusual for a Bollywood film) in helping generate civic activism among urban Indian youth.

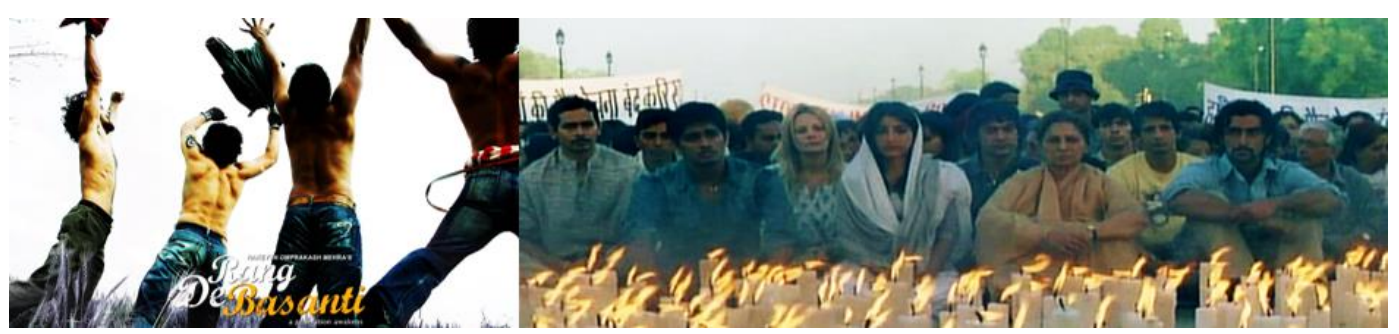

Figure 2- Still from the movie: Rang de Basanti - 2006

The movie narrated the gradual transformation of five college friends from happy, politically apathetic youngsters to anti-government rebels. The death of one of a close friend, a fighter jet pilot, acted as a catalyst, when the Aviation Minister falsely blames the pilot's 
foolhardiness for the crash instead of admitting the plane was a model long known to be defective, which the Minister had been bribed to procure. To protest, the friends organize a peaceful candlelight vigil at India Gate, a prominent landmark in the capital, New Delhi. The vigil is violently disrupted by the police, and the last third of the film shows the dramatic repercussions of this violence. The film's provocation is best captured in one line of dialogue: "No country is perfect. You have to make it perfect.

The movie impacted the audiences tremendously, especially the youth, who came to theatres because of its visually attractive ad campaign and star power. Though the director of the movie observed a significant post release that increased the discussion of the political issues in India. The frustration evident on some blogs as Ritesh (2012) said "The society will be ruined by these evil politicians. It's time to have a Rang De Basanti type resurgence"-this also reflected the frustrations showcased in the film's final moments. Within few weeks after the release of the movie, the change was easily seen in the air as people were unexpectedly moved by the film's story and ideology. This movie hence acted as an emergency-wake up call for the youth in India to take the cause of freedom seriously.

\subsection{Flash activism and flash fandom - Case 1}

The movie rang de basanti generated the civic activism among the Urban Indian Youth who aimed at securing justice in a high- profile murder case.

"Movie's most prominent impact was on the ongoing real-life where on April 29 1999 night, lall, young son of high ranking politician shot the 34 year old fashion model who was doubling as a waitress as a part of publicity campaign for a newly opened fancy restaurants in Delhi as she refused to serve him the drinks after the closing time. Since its common in India, the case dragged on in the courts for several years, during which period many witnesses withdrawn and the murder weapon went missing. Here media played an important role in shaping the societies and hence, the news got hyped. A day after the acquittal, a Times of India headline screamed, "No One Killed Jessica." NDTV, a 24-hour news channel, submitted to the president of India the more than 200,000 cell.

Few days after the verdict, Tehelka, an Indian weekly, sent an anonymous text message: "If the Jessica case has upset you, show you care. There is a protest gathering at India Gate next Saturday, March 4 at 5.30pm. Be there. Help keep up the pressure. Demand justice." It is not clear whether Tehelka deliberately chose India Gate to draw a parallel to RDB. The following evening about 2,500 people, many of them students, gathered for a candlelight rally at India Gate. This is noteworthy for many reasons. Yet what is most remarkable is that the protest was a replication of the crucial scene of a candlelight vigil at India Gate in Rang De Basanti, which had been released six weeks prior and was firmly alive in public memory and blogosphere discourse. Ritesh (2012)

Undoubtedly, the movie became a force, which had a direct impact on the community engagement. Though nothing happened after the protest, but people witnessed unity among themselves and India Gate then visualised as a place of protest rather than the a picnic spot. 


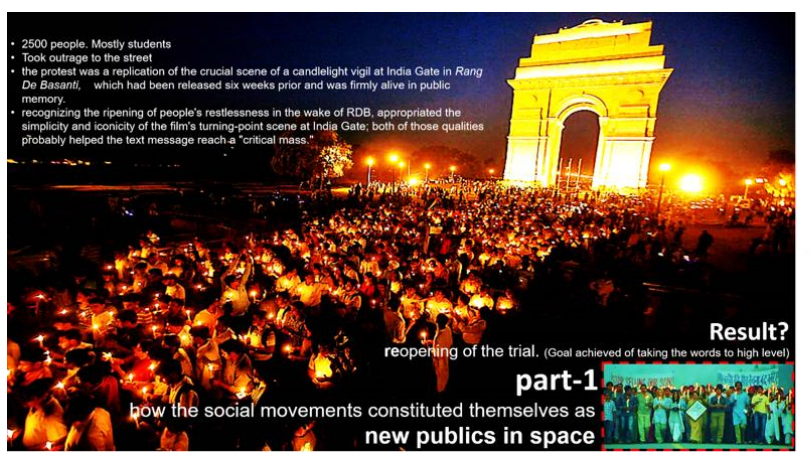

Flash activism \& flash fandom RDB Syndrome

Flash activism is a temporary social mobilization around particular civic issue, it may or may not have a clear cut goals, and may or may not achieve these goals.

Factors are responsible for this mobilization:

An existing group of people(specifically, a fandom, more below) already sensitive to and wishing to foster a civic ethos. External triggers, which may be cultural media artifacts like film, music, theater and television.

Principles of bottom-up emergence

- Suddenness of self-organisation

Manifestation of a flash fandom in the form of flash activism

Figure 3 - New public in space

\section{3. "Nirbhaya" Rape: Isolated Phenomenon or Social Change? - Case $\mathbf{2}$}

This brutal attack took place on $16^{\text {th }}$ December 2016 where a 23-year-old Jyoti singh, a premedical student who was returning home with her male friend boarded an off-duty bus, which already had six other persons including the bus driver. However, what happened next shook the whole nation, the girl was raped by six men in the moving bus while her friend was beaten up and thrown down from the bus. The victim suffered grievous bodily harm due to the terrible attack and the insertion of iron rod in her intestines caused serious injuries in her abdomen, intestines and genital organs.

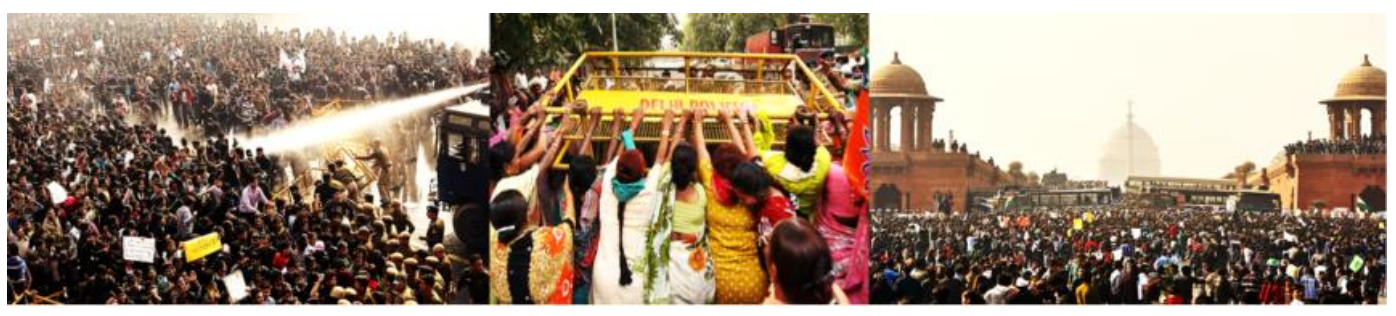

Figure 4 - Protests at India Gate

This incident made a huge hype worldwide and gained international sympathy. People from all over the world came together for this case and demanded justice for the survivor. This social movement was successful in creating an impact in India's history and demanding the rights for girl and her family. However, media had a mixed reaction in this case due to the political pressure. Nevertheless, because of this popular case worldwide, protestors succeeded in getting the justice sue to which criminals were hanged until death.

\section{Key Concepts}

\subsection{Right to the city}

Lefebvre (1996, p.158) summarizes the idea as a "demand... [for] a transformed and renewed access to urban life". Harvey (2008) described it as follows: "The right to the city is far more than the individual liberty to access urban resources: it is a right to change ourselves by changing the city. A right to the city empowers a new citizen, who is not only simply a user of the city but a participant in its creation and interpretation." Lefebvre (1991, pp.381-383) claims that through a subordinate group's challenge to a ruling group's claim, space is socially produced, contested and the space changed the space itself over the time. 
According to Lefebvre (1991) the space is actively produced, not only in its physical disposition but its social meaning, by the activities that go on in it, or that go on in some spaces but not others. He suggests imagining and reconstituting a very different kind of city, which incorporated and enriched its context.

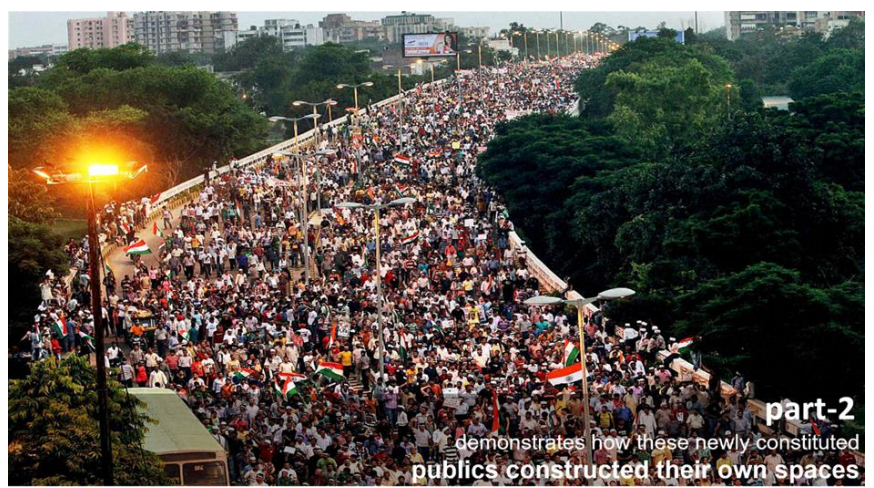

He argued that space must be understood as more than a neutral container of activity. The recognition of a right to the city would make more practical the right of users to make known their ideas on the space and time of their activities in the urban (Lefebvre, 1995: 34).

Figure 5 - Protestors depicting the right to the city on the bridge and occupying the space

Therefore, public space becomes a tool for the not visible conflict to come in surface. However, according Sassen (1991) the huge post-credit crunch buying up of urban buildings by corporations led to significant implications for equity, democracy and rights. While Castell's (1983, pp.319-320) criteria for a successful urban movement was if a space is occupied by the movement then it gives it a physical presence, a location identity, a place that can be identified with the movement that visitors can come to, and where adherents can meet.

\subsection{Local government}

Chandler (2001, pp.1-34) defines local government as "the authorities and dependent agencies that are established by Parliament to provide a range of specified services and represent the general interests of a specific area under the direction of a locally elected council. [...] They are charged with powers to promote the 'well-being' of their area in respect to economic, social and environmental concerns.

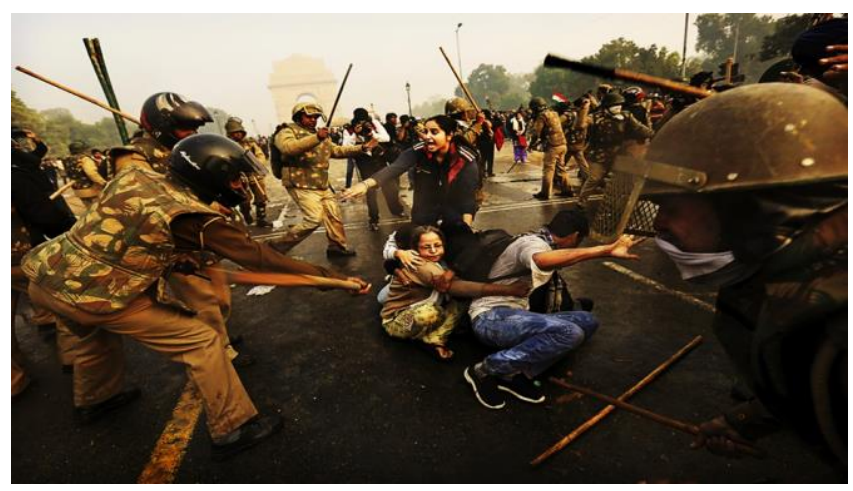

The modern local authority is therefore seen to have a wider role than providing a range of services largely concerned with social welfare, but is to be the lead agency in the overall economic and social development of their area".

Figure 6 - Reaction of the government pictured by a news channel 


\subsection{Social movements}

Sociology teaches that social movements go through the natural stages of maturation. This is very well explained in the article "exploring the role of philanthropy in supporting movements" (Sammen, 2015) that summarizes this phenomenon as:

"Movements are fluid and evolve differently based on political, economic, and social circumstances. After they emerge, movements generally coalesce around an identity and vision, and then sometimes they are formalized through public awareness campaigns and network development. Over time, movements achieve successes and suffer setbacks, might face counter-movements or generate new movements, and produce a variety of outcomes."

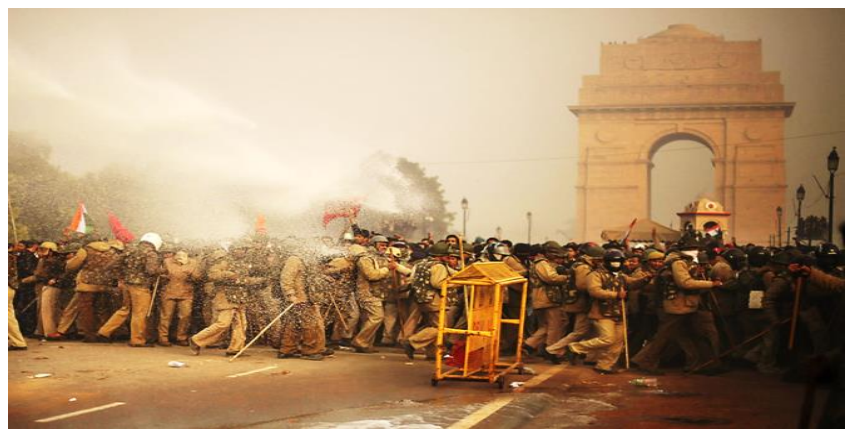

Hence the social movement is an effort - a memory that helps in bringing about a change in the society. It may also resist a change or change completely by either acting as reform movements or as revolutionary movements.

Figure 7 - People's reaction even after the denial from the government

\subsection{Social Media}

Social media is used for both communication and information, which involved movement in a variety of capacities.

Technology does not determine society: it is society, and can only be understood in social terms as a social practice. This means that the uses of wireless communication are fundamentally shaped and modified by people and organizations, on the basis of their interest, values, habits, and projects.

Castells, (2007, p.246)

...Social media have become coordinating tools for nearly all of the world's political movements, just as most of the world's authoritarian governments (and, alarmingly, an increasing number of democratic ones) are trying to limit access to it. In response, the U.S. State department has committed itself to "Internet freedom" as specific policy aim. Arguing for the right of the people to use Internet freely is an appropriate policy for the United States, both because it aligns with the strategic goal of strengthening civil society worldwide and because it resonates with American beliefs about freedom of expression

Clay Shirky, $(2011$, p.1) 


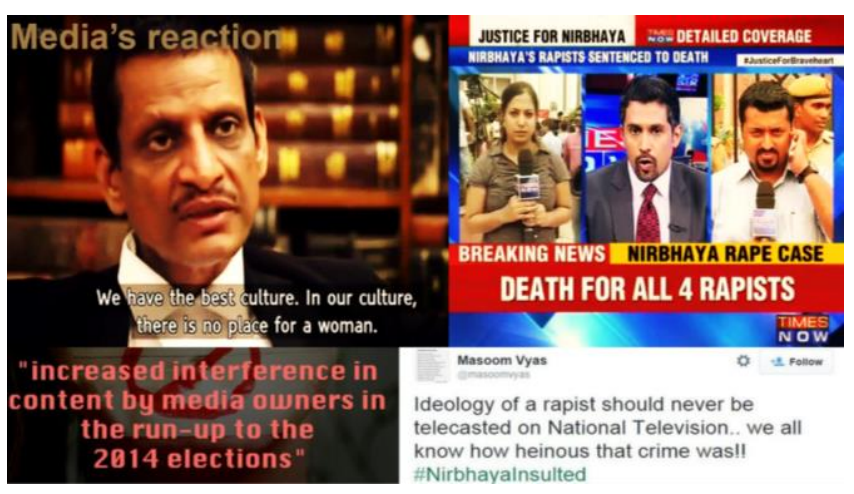

Figure 8- Media's reaction
There is a relationship between traditional and social media which plays an important role in commanding the society for social movements.

\subsection{Assumptions on the literature}

The existing literature about the interrelations between the urban social movements, the governments, media and the public, as well as the tensions and the conflict of interests, which finally cause the actual conflicts, is very rich. They also focus in the processes followed by the social movements, in order for them to be legitimate and -after all- successful. Nevertheless, their research aims lead them to examine these cases mainly from the point of the movements. Thus, there is a lack of information and conclusions about the role of the local governments, their dependence on the private investors and their vulnerability to political pressure. Other scholars (Hackworth, Sbragia, Chandler, etc.) deepen their research in the role of local governments in recent decades and thus, their inability to flexibly adapt to the local society needs.

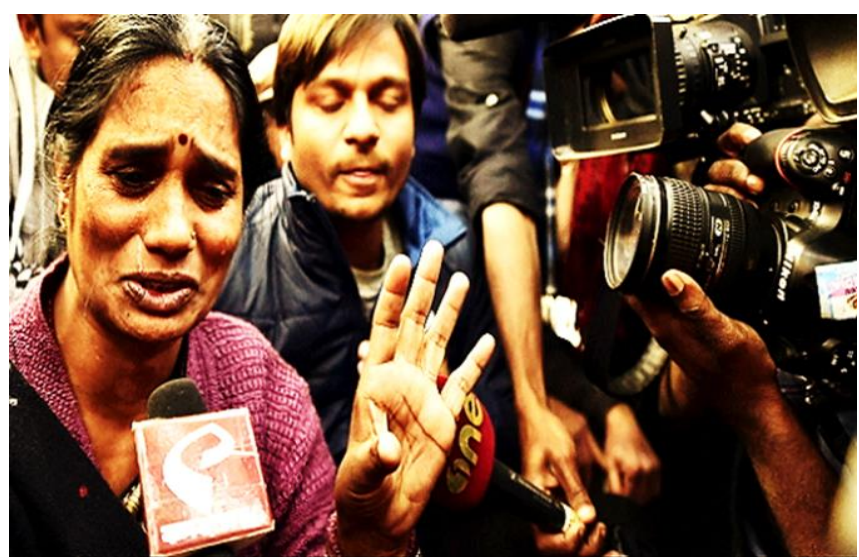

But their approaches tend to focus on the structural inflexibilities caused by the national or international regulations imposed rather than examining the relation of forces between social movements and local leaderships and how local leaderships can -or can't- adapt to the political pressure from multiple actors/interests.

Figure 9 - Survivor's mother request in the media, asking for justice

\section{Conclusions}

Spaces are themselves agents for change. Hence, Changed spaces will change the practice. (Dianna,2006, p.1.1)

Both Nirbhaya rape case and No one killed Jessica stands out as social movements because of their unique identity and long lasting influence. Instead of losing its acknowledgment and acceptability, the movements have gained some political aspects. These movements helped 
in creating a collective identity, which became stronger by time and influenced more people to join. Urban space acts as a 'void' between the building such s streets, plazas an parks that enables the movement. These plazas are viewed as a frivolity, an unnecessary drain on the resources or the use of the precious urban space. These 'places' are chosen by the people for social movements on the basis of the location as they act as major public destination which is built by precious commodities in an urban setting like local economies, civic pride , social connection and human happiness. A place is generally identified to something which does not change; their 'sense of place', 'character' or 'identity' which is relatively stable.

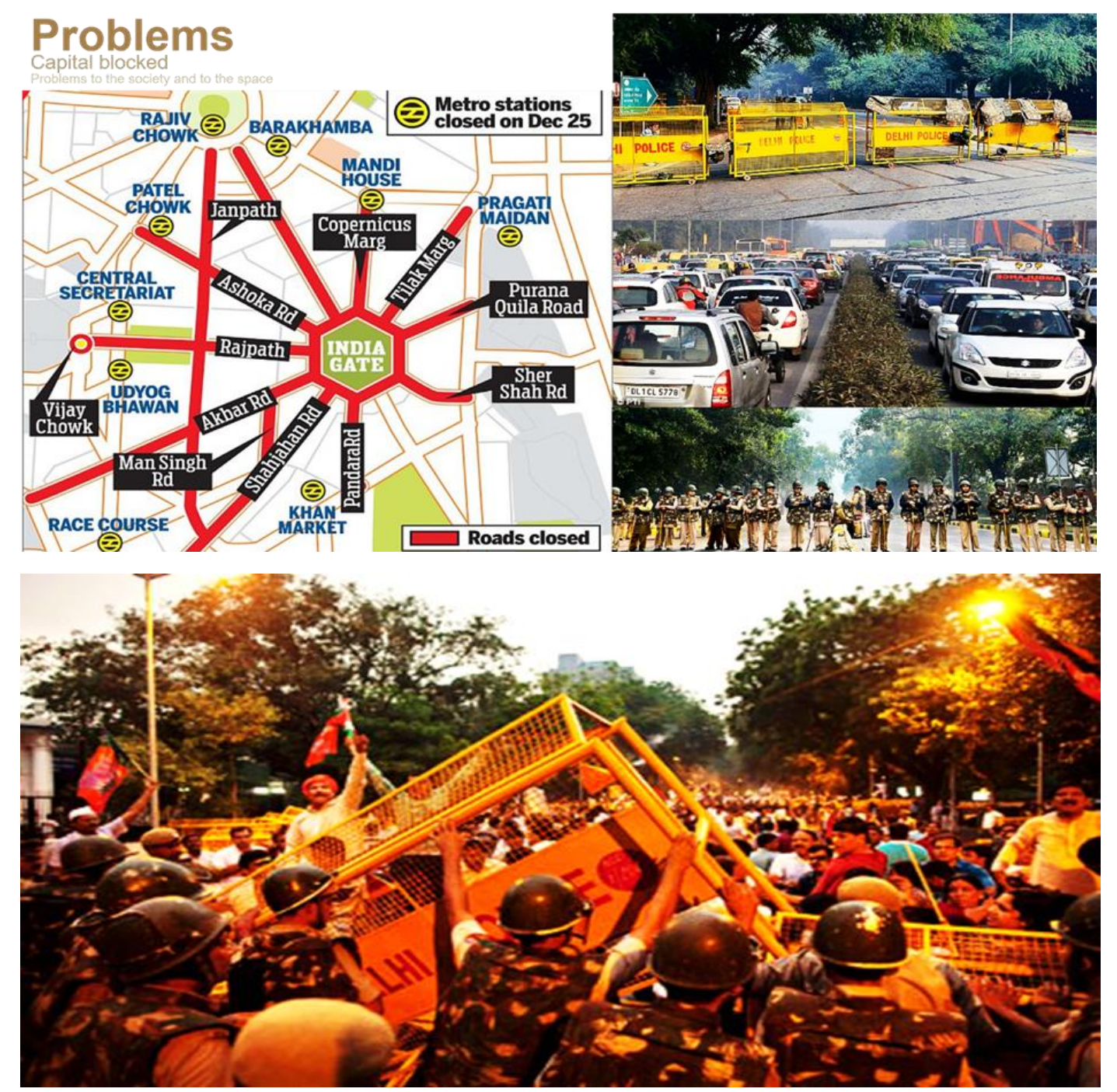

Figure 10 - Strict restriction on public movement $\&$ rebellious reaction both by the public $\&$ the government

For a successful social movement location also plays and important role in reaching the voice to the masses. The social movement happens either in a place which is used by people on a daily purpose so that it creates the problem for the public and hence the voice reaches the government. On the contrary, the other approach is to select a place which is historically or politically important. India Gate fits into both the categories. It is a quest for an essence of a place which is based majorly on the primordial past, a place which is abstracted from its instances in everyday life and consciously attempts in creating place making. Since it's located in the city centre, it's a perfect place for the manifestation. 
While Kilburn may have a character of its own, it is absolutely not a seamless, coherent identity, a single sense of place which everyone shares ... If it is now recognized that people have multiple identities, then the same point can be made in relation to places. Moreover, such multiple identities can be either, or both, a source of richness or a source of conflict. (Massey 1993: 65)

\section{Delhi}

Developed as an aggregative identity in perpetual transformation as True spaces of becoming in which the public and the space is continuously transformed \& reinvented earlier as picnic spot and now as a Space of conflict. Protesting space but later

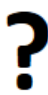

Hence, India gate is a place of formation, a place in the state of becoming as it is in the state of continuous change.

\section{References}

Acharya, S. (2016) Marginalization in Globalizing Delhi: Issues of Land, Livelihoods and Health. New York City, Springer.

Amoroso, N (2010) The Exposed City: Mapping the Urban Invisibles. United Kingdom, Routledge.

Castells, M. (1983) The City and the Grassroots: A Cross-cultural Theory of Urban Social Movements. Berkeley and Los Angeles CA: University of California Press.

Castells, M. (2004). The Power of Identity, (2nd edn.), Blackwell, Oxford/Malden.

Chandler, J.A. (2001). Local Government Today (3rd edition). Manchester \& New York: Manchester University Press.

Christiansen, J. (2009). Four Stages of Social Movements. MA: EBSCO Research Starters.

Eder, K. (1993). New Politics of Class: Social Movements and Cultural Dynamics in Advanced Societies, SAGE, London 
Eyerman, R., and Jamison, A. (1991). Social Movements. A Cognitive Approach, Polity, Cambridge.

Falahat, S. (2013) Re-imaging the city -- A new conceptualisation of the urban logic of the Islamic city. New York City, Springer.

Fuchs, C. The self-organization of social Movements(2006) Systemic Practice and Action Research, Vol. 19, No. 1 (pp.1-37).

Gamson, W. A., and Meyer, D. S. (1996). Framing political opportunity. In McAdam, D., McCarthy, J., and Zald, M. N. (eds.), Comparative Perspectives on Social Movements, Cambridge University Press, Cambridge, pp. 275-290.

Global Platform for the Right to the City. What's the right to the city? Inputs for the New Urban Agenda. https://www.escr-net.org/sites/default/files/what_r2c_digital.pdf, (10.01.2017).

Harvey, D. (2008). The Right to the City. New Left Review, 53, September-October. https://newleftreview.org/II/53/david-harvey-the-right-to-the-city, (20.01.2017).

Harvey, D. (2012). Rebel Cities. From the Right to the City to the Urban Revolution. UK/US: Verso.

Lefebvre, H. (1968). Le Droit à la ville [The right to the city] (2nd ed.). Paris, France: Anthropos.

Lefebvre, H. (1991). The production of space (N. Donaldson-Smith, Trans.). Oxford, England: Basil Blackwell.

Lowe, S. (1986). Urban social movements: the city after Castells. United Kingdom: Palgrave Macmillan.

Manekar, P. (1999) Screening Culture, Viewing Politics: An Ethnography of Television, Womanhood. North Carolina, Duke University Press.

Melucci, A. (1985). The symbolic challenge of contemporary movements. Soc. Res. 52(4), 789-815

Sammel, J. (2015). The evolution of social movements. Corolado Coalition 03.08.2015.

http://www.ccmu.org/blog/the-evolution-of-social-movements/

Sassen, S. (2015). Who owns our cities and why this urban takeover should concern us all. The Guardian 24.11.2015. https://www.theguardian.com/cities/2015/nov/24/who-ownsour-cities-and-why-this-urban-takeover-should-concern-us-all, (24.01.2017).

Yadav, C (1987) Perceptual and Cognitive Image of the City. New Delhi, India: Concept Publishing Co.

Pautz, Michelle C. (2015) "Films can have a major influence on how people view government", LSE retrived from https://blogs.Ise.ac.uk/usappblog/2015/03/12/films-canhave-a-major-influence-on-how-people-view-government/

Clark, Eric (2012) "Social Movement \& Social Media- A qualitative study of Occupy Wall Street", Södertörn University retrived from http://www.divaportal.org/smash/get/diva2:539573/FULLTEXT01.p 